\title{
12 Lead Placement 1 Lead Missing
}

National Cancer Institute

\section{Source}

National Cancer Institute. 12 Lead Placement 1 Lead Missing. NCI Thesaurus. Code

C71125

An electrocardiogram (ECG) lead placement whereby 12 leadpoints are recorded but one standard lead position is missing therefore requiring a Mortara source consistency filter. 